\title{
PRESSURE-MELTING EFFECTS IN BASAL ICE OF TEMPERATE GLACIERS: LABORATORY STUDIES AND FIELD OBSERVATIONS UNDER GLACIER D'ARGENTIÈRE
}

\author{
By D. J. Goodman, \\ (Cavendish Laboratory, Madingley Road, Cambridge $\mathrm{CB}_{3}$ oHE, England)
}

G. C. P. KING,

(Department of Geodesy and Geophysics, Madingley Road, Cambridge $\mathrm{CB}_{3} \mathrm{oHZ}$, England)

D. H. M. Millar, and G. DE Q. Robin

(Scott Polar Research Institute, Lensfield Road, Cambridge CB2 IER, England)

Abstract. The suggestion that patches of basal ice may freeze to the bed of a glacier due to certain regelation effects has been tested in the laboratory by applying high hydrostatic pressures to ice samples at the pressure-melting point. During compression, ice temperatures follow the pressure-melting point closely, but after rapid decompression the ice temperature at first returns only half to three-quarters of the way to the pressure-melting point, after which it appears to warm by thermal conduction from outside the ice sample. If the moving ice at the base of a glacier behaves in the same way as it is exposed to changing pressure fields, frozen patches at bedrock are to be expected.

Records of strain variations in a tunnel beneath Glacier d'Argentière show two types of strain events. The first is a rapid jump or offset in the recorded strain, while the second are strain excursions, initiated by a change in strain over a period up to ten seconds, followed by a gradual recovery to the original strain over some minutes. It is suggested that the offset events are due to nearby stress release due to fracturing of frozen patches of ice at the bedrock while the strain-excursion events show the more distant adjustment of the glacial bed to the former events due to the time lags associated with changes of water-film thickness and regelation heat flow.

RÉSUMÉ. Effets de la fusion sous pression dans la glace du fond d'un glacier tempéré. Etudes en laboratoire et observations de terrain sous le glacier d'Argentière. L'hypothèse que des lambeaux de glace de fond peuvent adhérer au lit rocheux d'un glacier par certains effets de regel a été soumise à l'épreuve du laboratoire en appliquant de fortes pressions hydrostatiques à des échantillons de glace au point de fusion par pression. Pendant la période de compression, la température de la glace se règle exactement sur le point de fusion correspondant à la pression, mais après une décompression brutale, la température de la glace revient d'abord de seulement la moitié ou les trois-quarts du chemin qui la sépare du point de fusion sous pression, après quoi la température semble se réchauffer par conduction thermique depuis l'extérieur de l'échantillon. Si la glace en mouvement sur le fond d'un glacier se comporte de la méme manière lorsqu'il est exposé à des variations de pression, on peut s'attendre à la formation de lambeaux de glace de fond adhérant à la roche par regel.

Des enregistrements de variations de contraintes dans un tunnel creusé sous le glacier d'Argentière montre deux types d'événements. Le premier est un saut rapide ou un pic dans l'enregistrement des contraintes, tandis que les seconds sont de petites indentations de la courbe des contraintes commençant par une variation d'une durée allant jusqu'à to secondes suivies d'un retour graduel à la valeur originelle en quelques minutes. On suggère que les pics sont dûs à des relachements soudains par rupture dans le voisinage de zones adhérant à la roche par le gel, tandis que les indentations révèlent des ajustements se produisant plus loin, du lit glaciaire aux événements ci-dessus en raison du retard introduit par les variations dans l'épaisseur du film liquide et du flux de chaleur de regel.

Zusammenfassung. Druckschmelzeffekte im Eis am Untergrund temperierter Gletscher. Laboruntersuchungen und Feldbeobachtungen unter dem Glacier d'Argentière. Die Annahme, dass Flecken von Eis infolge gewisser Regelationseffekte an das Bett eines Gletschers anfrieren könnten, wurde im Labor durch Aufprägung hoher hydrostatischer Drucke auf Eisproben am Druckschmelzpunkt geprüft. Während der Kompression liegen die Eistemperaturen dicht am Druckschmelzpunkt, aber nach schneller Dekompression kehrt die Eistemperatur zuerst nur zur Hälfte bis drei Viertel des Weges zum Druckschmelzpunkt zurück, wonach es infolge der Wärmeleitung von ausserhalb der Probe zu warm zu sein scheint. Wenn das bewegte Eis am Grunde eines Gletschers sich gerade so verhält, als wäre es wechselnden Druckfeldern ausgesetzt, dann sind aufgefrorene Flecken am Felsbett zu erwarten.

Aufzeichnungen der Spannungsschwankungen in einem Tunnel unter dem Glacier d'Argentière zeigen zwei Typen von Spannungsreignissen. Der erste ist ein schneller Sprung oder Absatz in der Spannungsaufzeichnung, während der zweite in Spannungsausschlägen besteht, die mit einem Spannungswechsel über eine Periode bis zu ro Sekunden beginnen, gefolgt von einer allmählichein Rückkehr zur Ausgangsspannung 
in einigen Minuten. Es wird angenommen, dass die Sprungereignisse durch Druckabfall in der Nachbarschaft infolge des Abbruchs angefrorener Eisflecken vom Felsbett verursacht werden, während die Spannungsausschläge die weiter entfernte Anpassung des Gletscherbettes an die vorher genannten Ereignisse wiedergeben, die infolge der zeitlichen Verzögerung mit Schwankungen in der Dicke des Wasserfilms und mit dem Fluss von Regelationswärme verbunden ist.

\section{INTRODUGTION}

This paper describes results from two investigations designed to test the hypothesis that a temperate glacier may freeze to its bed in isolated patches. In the laboratory experiments an ice block, whose boundary was maintained at various temperatures close to the equilibrium melting temperature, was subjected to different hydrostatic loads for different periods, while careful measurements of the temperature (to $\pm 0.005 \mathrm{~K}$ ) were made at its centre with a thermocouple. In the field experiment, continuous records of strain down to $10^{-8}$ over a $10 \mathrm{~m}$ gauge length were made at three sites in two rock tunnels within $10 \mathrm{~m}$ of the ice/rock interface under the Glacier d'Argentière, Mont Blanc, France. The records show characteristic strain events lasting a few minutes that appear to be elastic changes in the rock resulting from changes in the surface tractions between the glacier and its bed.

Robin (1976) suggested two processes that would result in patches of the bed of a temperate glacier being colder than the pressure-melting point. The first process involves a heat-pump effect that is expected to occur during steady flow of a glacier over bedrock irregularities. The second process suggests that intermittent freezing of bedrock patches may result from time variations in the pressure of subglacial water and resultant changes of ice loading on bedrock protruberances.

The above processes depend on the assumption that if the hydrostatic pressure on a parcel of ice at the pressure-melting point is increased rapidly, the temperature through the parcel of ice will fall rapidly to the new pressure-melting point, the necessary heat balance being preserved by absorption of latent heat by melting within the ice mass. When the hydrostatic pressure is rapidly decreased it will quickly warm to the new warmer pressure-melting point as latent heat is absorbed by freezing of melt water only if there is sufficient melt water distributed throughout the parcel of ice. However if there is no melt water present, the ice will remain at the colder temperature of its former pressure-melting point until heat is supplied by conduction from the boundaries of the parcel or by the heat generated in deforming the ice mass.

The heat-pump hypothesis suggests that as basal glacier ice moves into a high-pressure zone up-stream of an obstacle and is cooled by increasing pressure, the resultant water is squeezed out through capillaries into the subglacial water film. Then when this ice moves on to regions of lower pressure, the ice remains cold because the capillaries have closed under pressure, and latent heat is no longer readily available. The effect may occur throughout the glacier sole of the order of decimetres or metres in thickness, and be sufficient to maintain cold patches of ice one or two metres across beneath a glacier moving at speeds of the order of I $\mathrm{m} \mathrm{d}^{-1}$.

The second process envisages the major part of the weight of a glacier being supported by a water film at relatively low pressure and a smaller fraction by areas of high pressure over bedrock humps. Since the total weight must balance the total basal (water) pressure over a wide area, an increase of the low water pressure will produce a proportionally greater drop in pressure over the smaller high-pressure areas. If sufficient latent heat from water is not available within this ice mass, then it will not adjust to the warmer pressure-melting point, but will freeze to the bed.

If frozen patches are caused by either process, they are likely to produce a change of traction with time between the glacier and bedrock, since the ice will adhere to the rock in the absence of a water film. Since such patches could be some tenths of a degree Celsius 
below pressure-melting point, the shear tractions could be quite large (at least o. I $\mathrm{MN} \mathrm{m}^{-2}$ ), and these would increase as the glacier moved forward. It would be expected, therefore, that from time to time a crack would run between the ice and the rock to relieve the stress. With a time constant, which depended on the diffusion of heat away from the crack faces, the crack would "heal" and the ice again become frozen to the rock. This effect would lead to a "jerky" sliding of the glacier over its bed.

Although Goldthwait (1973) observed jerky motion only at the upper surface of glaciers and not at bedrock, observations of the jerky nature of glacial sliding have been reported beneath Østerdalsisen in Norway by Theakstone ( 1967 ) who recorded the motion of a peg driven into the ice roof of a cavity beneath the glacier. Vivian and Bocquet (1973) also reported irregular sliding beneath Glacier d'Argentière. Care was taken to eliminate instrumental stick-slip in these observations, but the possibility of such effects remain. Our field observations give an independent indication of jerky sliding through our recording of strain events due to changing traction between the ice and rock.

\section{LABORATORY STUDIES}

\section{I. Introduction}

The laboratory experiments had two objects. The first was to confirm that the adjustment of pressure-melting point under increasing pressure took place immediately following application of pressure. The second was to see if the heat-pump process could be shown to take place under laboratory conditions. It was expected that the results of these experiments would also confirm the accepted coefficient of change of melting point with pressure.

\subsection{Apparatus}

The apparatus is shown in Figure I. Fine-grained snow formed by grinding ice (made from distilled water) in an electric coffee grinder, was packed in a cylinder around a small Chromel/ Alumel thermocouple supported at the end of a stainless-steel tube. Distilled water was added to the snow and allowed to freeze to form a polycrystalline ice cylinder with randomly

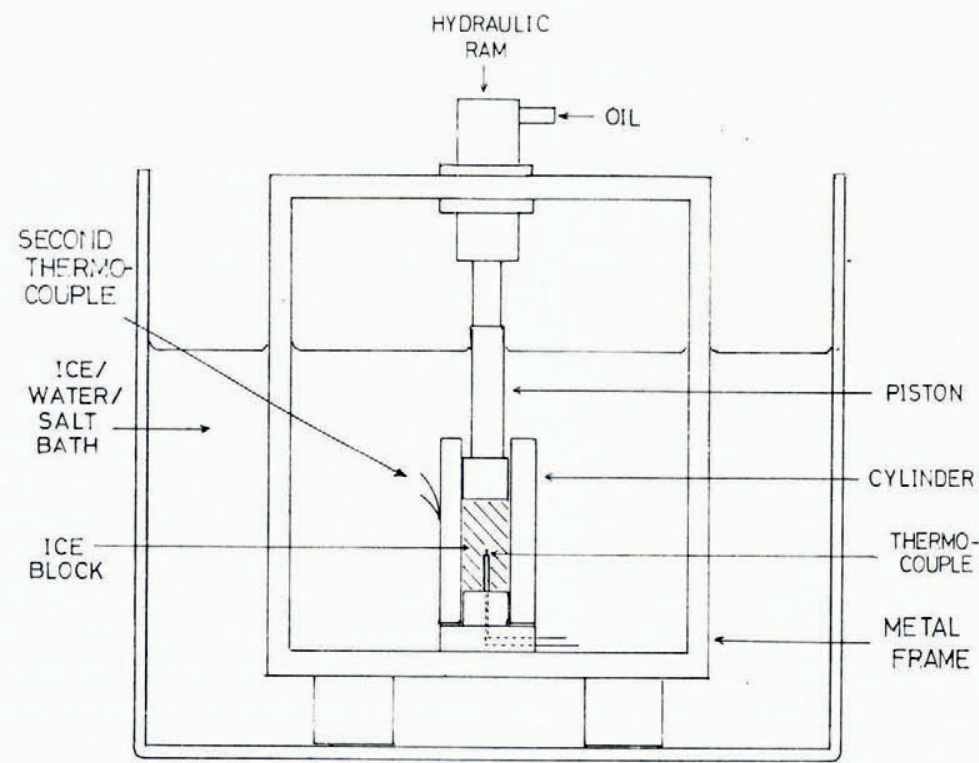

Fig. I. Apparatus used to load the ice at various hydrostatic pressures. 
orientated grains and many air bubbles. The cylinder and a close-fitting piston were then lowered into an ice/salt/water bath and left for about one hour in the bath until a steady temperature was recorded. Loads were then applied to the piston via a simple hydraulic system and press; the pressure applied to the ram was monitored with a gauge, and the E.M.F. from the thermocouple junction compared to a second thermocouple junction in a triple-point cell, amplified and recorded on a chart recorder. A second thermocouple was used to measure the temperature on the outside of the cylinder. Temperature changes of o.oor $\mathrm{K}$ could be resolved. The mixture in the ice/salt/water bath could be varied to change the temperature on the outside of the cylinder; the stress distribution in the ice block was assumed to be hydrostatic and equal to the load applied to the piston divided by its area. The temperature change in the middle of the ice block was measured for various boundary temperatures and changes in hydrostatic pressure.

\subsection{Results and discussion}

Compression of samples below the pressure-melting point shows adiabatic warming on compression that takes place at a similar rate to the increase of pressure. This indicates that our assumption that the hydrostatic pressure in the sample follows the changes of pressure of the hydraulic system is correct. When a constant pressure is left on the system (Fig. 2a), it then cools back to the ambient temperature with a time constant of the order of $30 \mathrm{~s}$ due to thermal conduction and the geometry of our experiment. When pressure is removed, adiabatic cooling of the order of $0.1 \mathrm{~K}$ takes place and the process is reversed. The magnitude of this cooling is similar to that of the warming, which confirms the adiabatic effect.

When the experiment is repeated on ice close to the pressure-melting point, we see in Figure $2 \mathrm{~b}$ that instead of adiabatic warming due to compression, the sample cools rapidly as the pressure is applied so that there is no detectable time lag (less than $2 \mathrm{~s}$ ) before the thermocouple records the new pressure-melting point within the sample. This shows that this temperature change is due to processes within the ice mass. Thermodynamic reasons in line with this argument given by A. B. Pippard (personal communication) are presented in the Appendix.

The above observation indicates that where temperate ice at the base of a glacier moves into a zone of increasing pressure, the temperature field will be determined directly by the pressure field throughout the ice mass.

The immediate lowering of temperature at 50 bars was $0.49 \pm 0.01 \mathrm{~K}$ (Fig. 2b), and at I Oo bars I.05 to.o I K (Fig. 2C). This is greater than the lowering expected for pure ice of $0.0074 \mathrm{~K}$ per bar, and shows the additional lowering of $0.0024 \mathrm{~K}$ per bar due to presence of air dissolved in water (Harrison, 1972). The main uncertainty in these observations is the measurement of pressure, which was read off an industrial pressure gauge.

When pressure is removed from the sample, which takes around two seconds, the temperature of the central thermocouple rises over the same time interval by a little over half of its previous fall in temperature, and it continues to rise slowly for one to five minutes to return to the temperature of the water bath (Fig. 2d). The time constant for this rise (1/e of temperature after release of pressure of 50 bars) varies from roughly $40 \mathrm{~s}$ after the pressure was applied for about $5 \mathrm{~s}, 60 \mathrm{~s}$ after applying the pressure for $90 \mathrm{~s}$, and go s after applying the pressure for $300 \mathrm{~s}$ (Fig. 2b). We interpret these results as indicating that perhaps half the free water produced by compression remains distributed throughout the sample, while the remainder escapes possibly around the piston. For the run shown in Figure $2 \mathrm{e}$ a layer of around $0.5 \mathrm{~cm}$ of compressed talc was inserted above the ice, about $2 \mathrm{~mm}$ from the thermocouple, to see if this would absorb a large fraction of water produced during compression. No significant change is apparent. 
a)

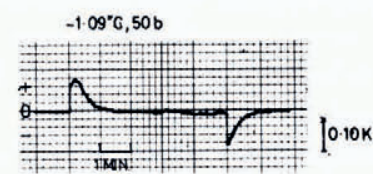

b)

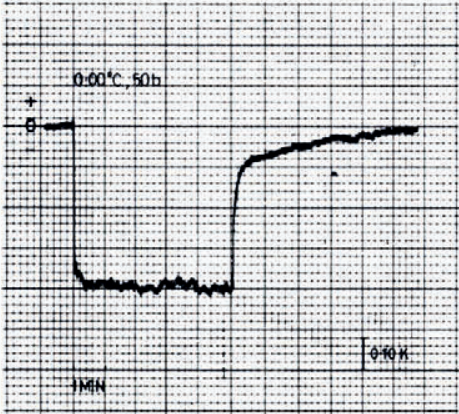

c)

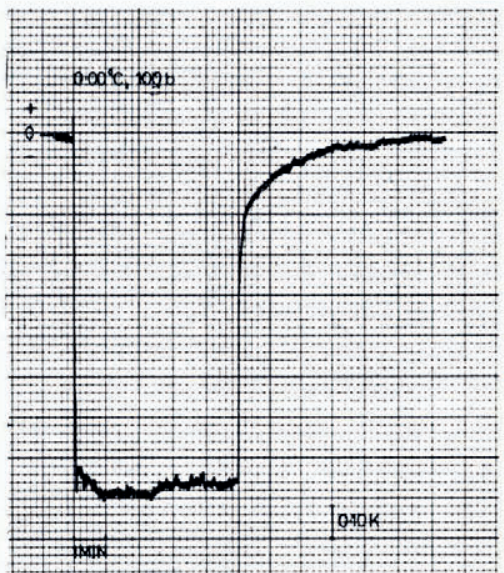

d)
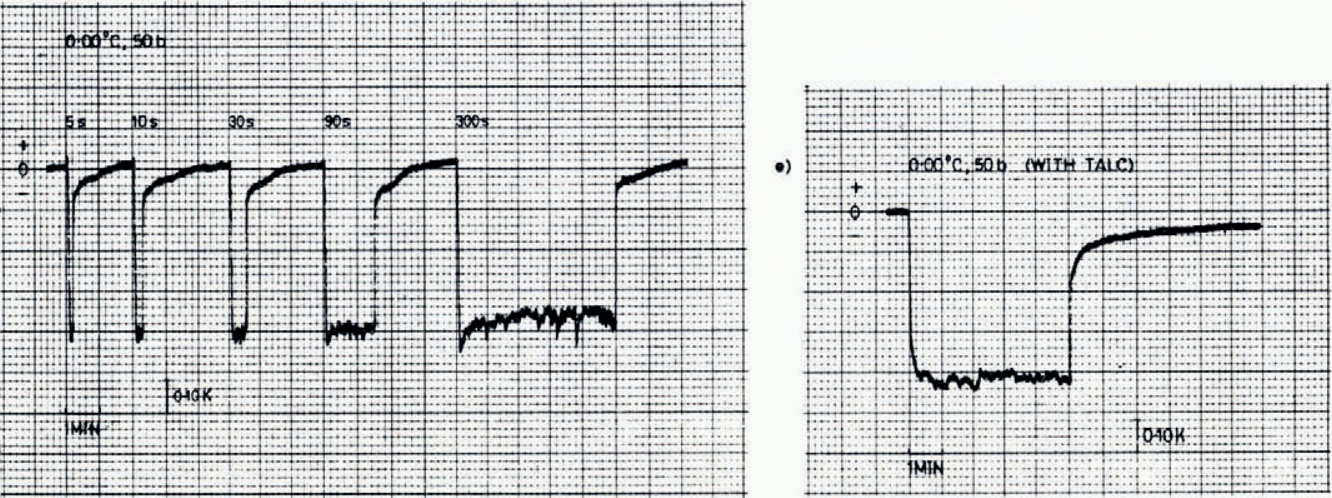

Fig. 2. Temperature changes produced by loading and unloading the ice block: (a) ice at $-1.09^{\circ} \mathrm{C}$, load of 5 o bars for 5 min; $(b)$ ice at $0.00^{\circ} \mathrm{C}$, load of 50 bars for $5 \mathrm{~min} ;(c)$ ice at $0.00^{\circ} \mathrm{C}$, load of 100 bars for $5 \mathrm{~min} ;(d)$ ice at o.oo ${ }^{\circ} \mathrm{C}$, load of 50 bars for times from $5 \mathrm{~s}$ to $300 \mathrm{~s}$ as shown; $(e)$ ice at $0.00^{\circ} \mathrm{C}$, load of 50 bars, with absorbent layer of talc compressed in chamber.

The time constant for warming up following decompression of samples at $0.00^{\circ} \mathrm{C}$ is not less than that for decompression at $-\mathrm{I} .09^{\circ} \mathrm{C}$, when no water is present. This indicates that the later part of the warming of samples initially at $0.00^{\circ} \mathrm{C}$ is due to thermal conduction processes, probably from the boundaries of the cylinder. It is clear that some redistribution of water within the cylinder has taken place, especially in the vicinity of the thermocouple. The major redistribution clearly takes place within $5 \mathrm{~s}$ at 50 bars pressure. To this extent we appear to have confirmed the presence of heat-pumping in the cylinder, and thus its probable importance beneath a glacier.

\section{Continuous measurements of the strain changes in the rock under Glacier} D'ARGENTIÈre

\subsection{Instrumentation}

Under Glacier d'Argentière, Mont Blanc, France, a network of tunnels has been dug for a hydro-electric scheme. Some of these tunnels pass very close to the bed of the glacier. In 
two tunnels, which were within $10 \mathrm{~m}$ of the bed, three geophysical wire strainmeters (with a resolution of $\mathrm{I}$ in $\mathrm{IO}^{8}$ strain, and $10 \mathrm{~m}$ gauge lengths) were installed and run for threeweek periods between September 1975 and July 1976. Wire strainmeters have been used successfully for the measurement of earth tides (King and Bilham, 1973), and were not modified for this experiment. Data were recorded on three separate chart recorders, although the instruments did have a common a.c. power supply. A plan of the tunnel network at the site appears in Figure 3, and a profile showing the relation of the strainmeters to the glacier bed appears in Figure 4. The vertical plane containing the strainmeters was approximately perpendicular to the direction of flow of the glacier at the site. At this point, under about $80 \mathrm{~m}$ of ice, the glacier moves over a rock bar; about $20 \mathrm{~m}$ down-glacier of the instruments, a series of cavities have formed across the glacier, and on the surface there is an extensive crevasse field.

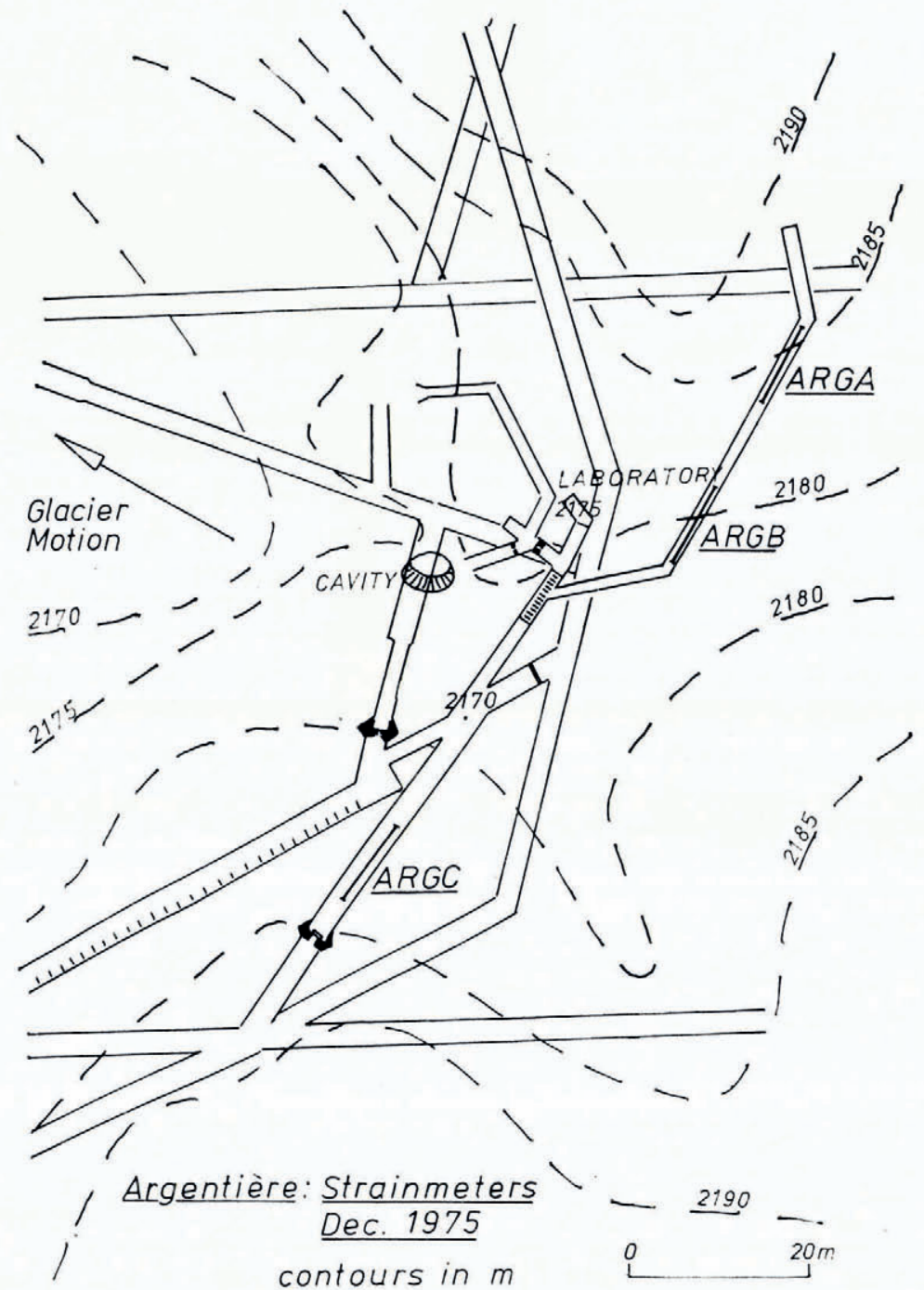

Fig. 3. A plan of the tunnel network under the Glacier d'Argentière. The contours are of the rock bed. The ice thickness above the cavity is about $80 \mathrm{~m}$. ARGA, ARGB, and ARGC are the sites of the three wire strainmeters. 
The glacier has been well studied by R. A. Vivian and his co-workers. In particular they have installed in one of the cavities a device for measuring the sliding speed of the glacier (Vivian and Bocquet, I973), and have studied the fluctuations in volume of water discharged (Vivian and Zumstein, 1973).

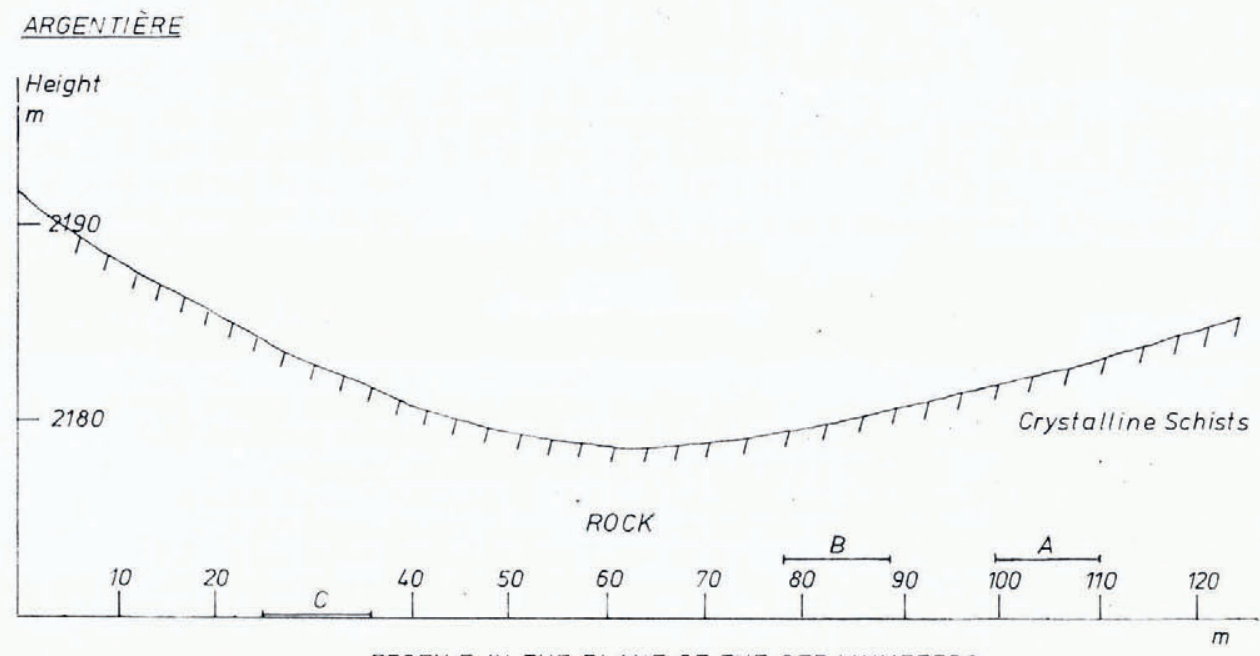

PROFILE IN THE PLANE OF THE STRAINMETERS

Fig. 4. The profile of the glacier bed in the plane of the three strainmeters.

\subsection{Observations}

Good-quality strain data were collected on instruments A and C for three-week periods in September 1975, January 1976, and April 1976. The records all showed long-period strain changes, probably due to Earth tides, but also frequent but not regular strain excursions. Two types of events were observed; simple small offsets, and strain excursions which began with a very rapid (but not instantaneous) change followed by a slow decay back to the original value. Some examples are shown in Figure 5. The strain excursion events are strikingly similar to events observed on tilt-meters close to the San Andreas fault in California (McHugh and Johnston, I977); on the fault the surfaces move relative to each other at only about Io $\mathrm{mm}$ per year (see Fig. 6).

The time between events for each instrument has been carefully analysed, and the resulting distributions compared with an exponential distribution, using a chi-squared test to examine whether the events are random. For each of the time series considered, the distribution was found to be exponential with an $\alpha$ value of better than 0.05 ; at this level of significance the events are random. Histograms showing the distributions are shown in Figure 7.

Correlations between instruments $\mathrm{A}$ and $\mathrm{C}$ were also examined over a two-week period, and in $30 \%$ of the events the time at which they occurred was the same within the error of the time determination (c. 10 min). Because the instruments were some $70 \mathrm{~m}$ apart in different tunnels, and had different chart recorders and stabilized power supplies, the latter result is good evidence that the events are indeed real. In some cases, an offset event on one meter appeared to coincide with a strain excursion event on the other instrument.

For three days in April 1976 a vertical seismometer was operated alongside the strainmeter A. Many seismic events were observed when the magnetic tapes were replayed; a large proportion of the events had signatures which were similar to seismograms presented by 

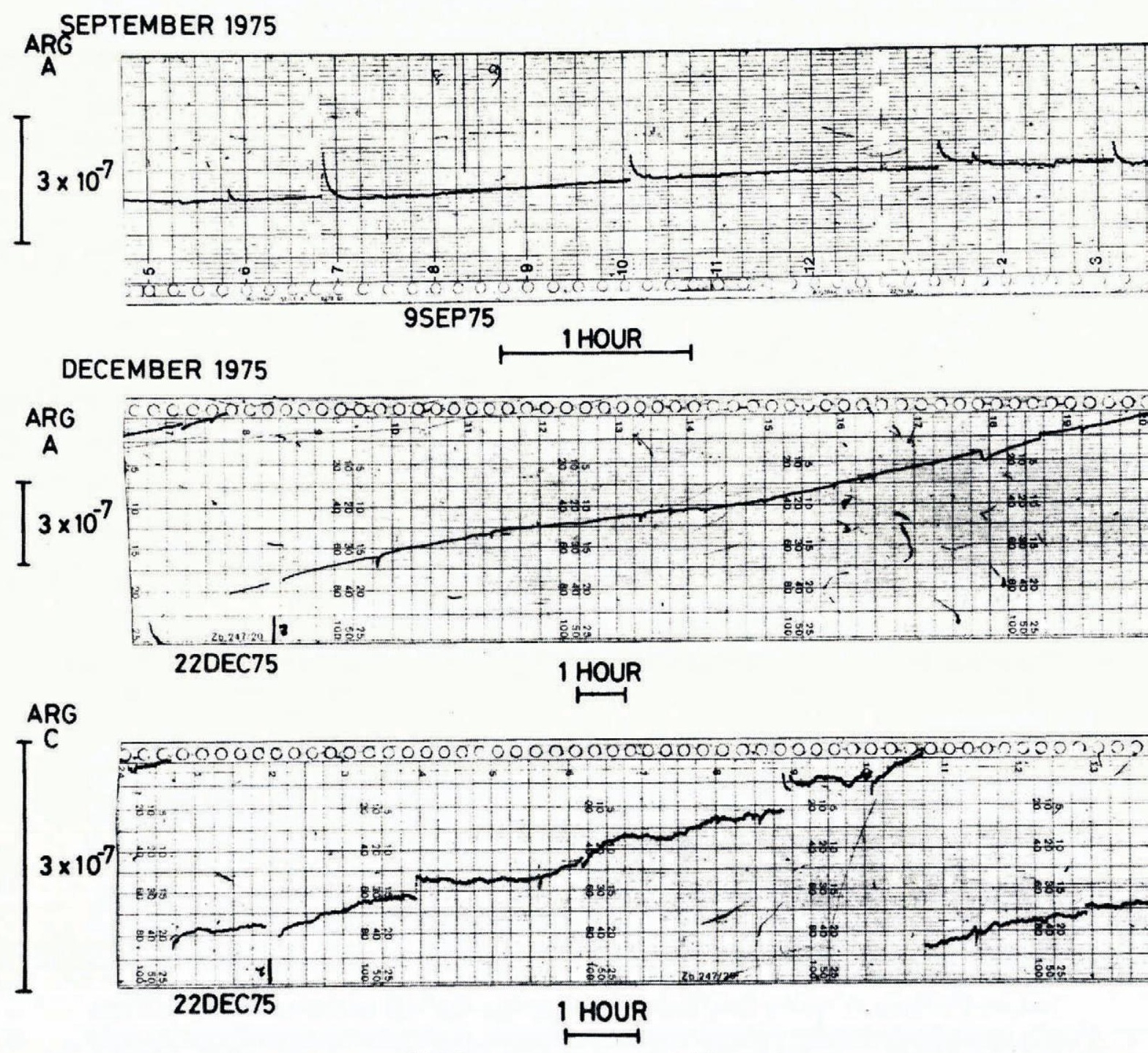

Fig. 5. Some examples of the events observed on the records of the strainmeters. The trace is a measure of the elastic strain changes in the rock tunnel as the glacier slides over its bed above the tunnel.

Neave and Savage (1970), VanWormer and Berg (1973), or Weaver and Malone (1976), who installed geophones or seismometers close to glaciers. Some of the seismic events could be correlated with events observed on the records from the strainmeters.

A comparison of events at different times of the year shows two features. Individual events in September show about three times the magnitude of the strain jump seen in April, when small offset events form a higher proportion of the total. To compare the time interval between events in summer and other seasons, we show on the diagrams the number of events per day on individual strainmeters at different times of the year. We see that in September 
B

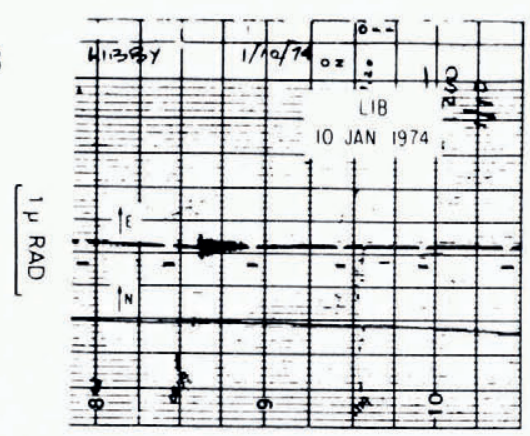

D

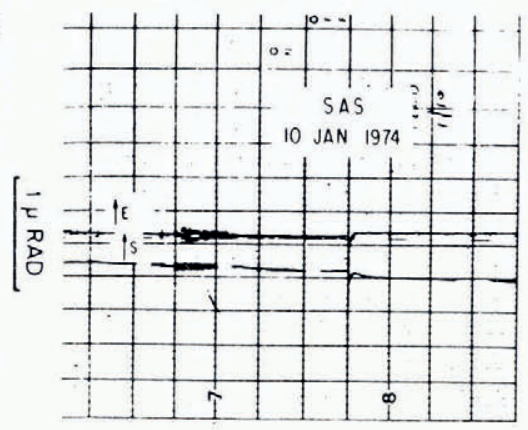

$1 \mathrm{HR}$

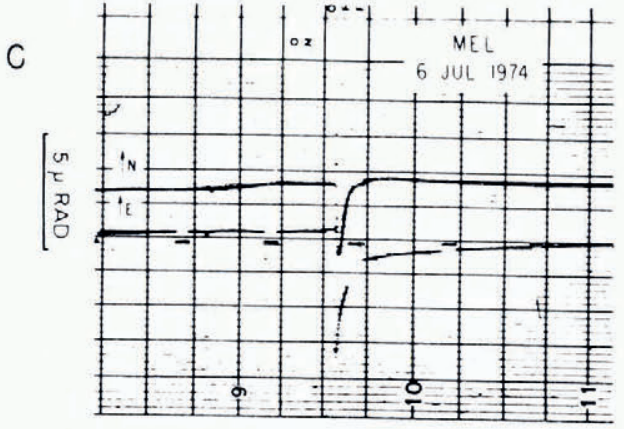

$E$

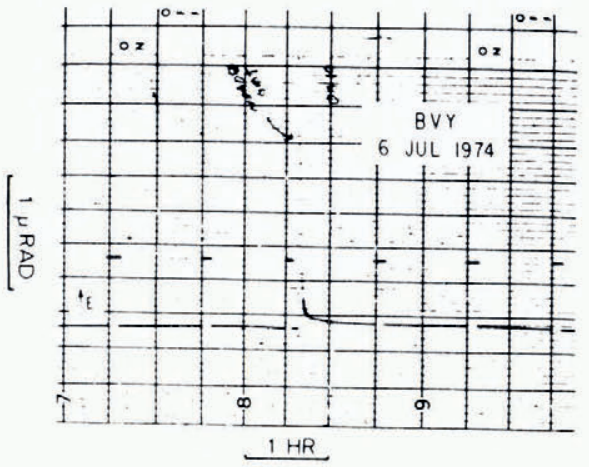

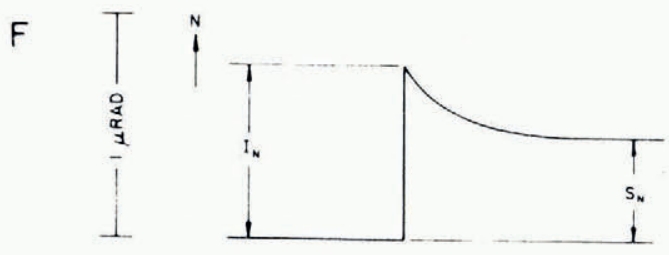

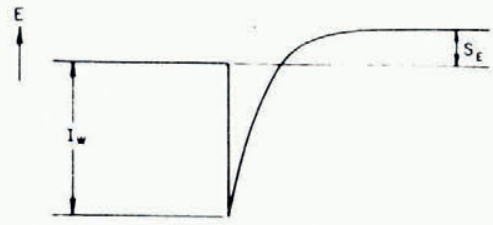

$\longmapsto$ I HR -

Fig. 6. Similar events observed in bore holes close to the San Andreas fault, California (from McHugh and Johnston, 1977).

events take place around twice as frequently as in December-January and nearly three times as frequently as in April.

Vivian (1975) gives a table of glacier sliding speeds in the area of our observations for I97 1 to 1973. The sliding speed in April of $17.4 \mathrm{~mm} \mathrm{~h}^{-1}$ was the slowest of the year, while it was $26.6 \mathrm{~mm} \mathrm{~h}^{-1}$ in September, a similar value to August, after more rapid sliding in June and July. 


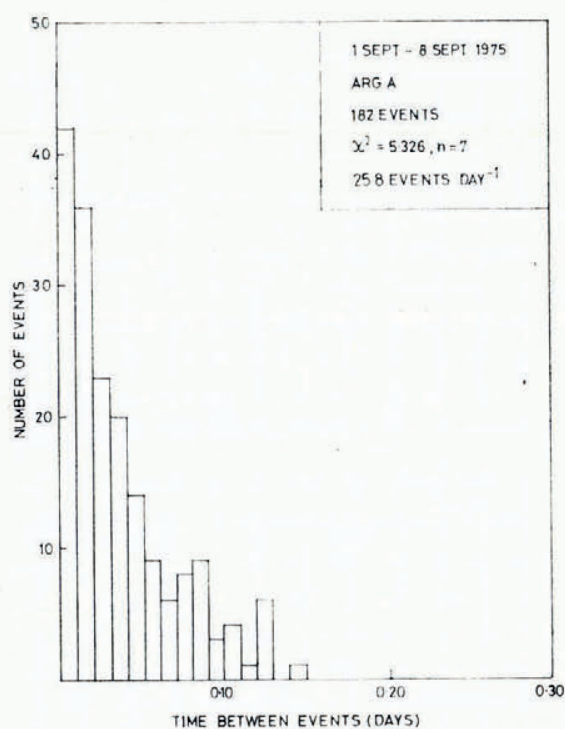

(a)

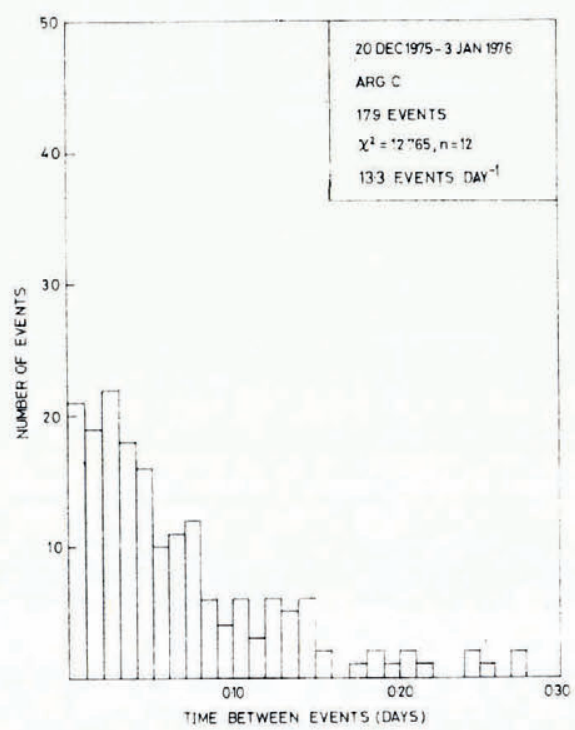

(c)

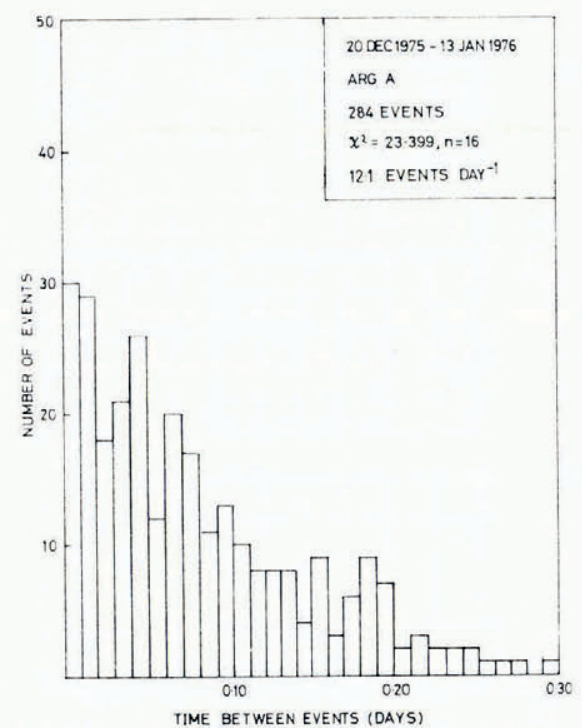

(b)

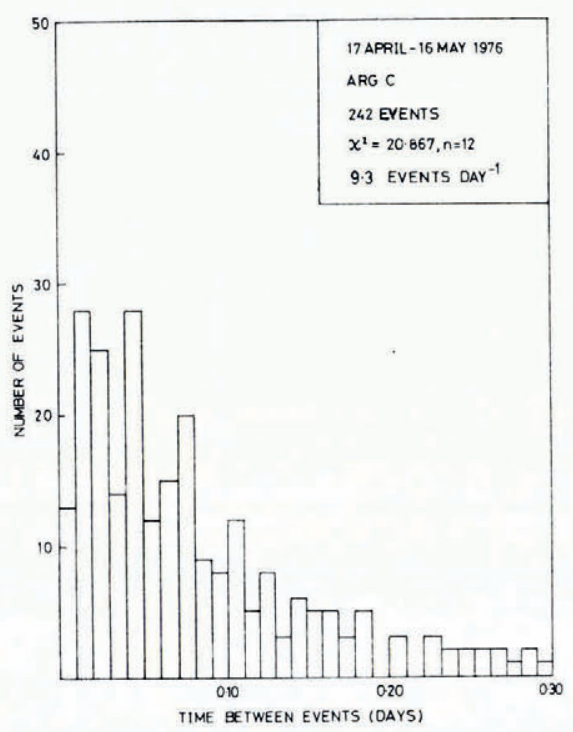

(d)

Fig. 7. Histograms showing number of events on individual strainmeters as a function of the time between events: (a) strainmeter $A$, I to 8 September 1975; (b) strainmeter A, 20 December 1975 to 13 Fanuary 1976; (c) strainmeter C, 20 December 1975 to 3 Fanuary 1976 ; (d) strainmeter C, 17 April to 16 May 1976.

A search for a diurnal variation in the interval between events failed to show any such variation, although this variation might be expected in summer if the variations of pressure of the basal water film follow the pattern of water discharge in the main subglacial drainage system.

While seasonal variation indicates some possible link between events and summertime conditions of faster sliding and variable subglacial water supply, this is not apparent in the diurnal pattern. 


\subsection{Possible explanations of strain events}

A simple picture of such events is that a frozen patch which adheres to bedrock will experience an ever-increasing stress as the glacier moves forward so that eventually a crack runs part or all the way across the frozen patch and relieves the stress. Goodman (unpublished) has calculated the stress field due to a square patch with a side of $2 \mathrm{~m}$ and finds that if a shear traction of o. I $\mathrm{MN} \mathrm{m}^{-2}$ were applied to the patch, the strain field would be large enough at Io $\mathrm{m}$ to record strains of similar magnitude to those in Figure 2. Furthermore the strain field from a point force on the surface falls off as $\mathrm{I} / r^{4}$, where $r$ is the distance from the force.

The apparent correlation of some seismic events with records from strainmeter A supports the idea of fast crack propagation due to stress. While this would be consistent with our simple offset events, the typical rise time of our strain excursion of the order of $\mathrm{Ios}$ on the strainmeter does not fit this model. The coincidence in time between the two types of event in some observations suggests that they are associated in a common mechanism. Consider the effect if the frozen patch is not immediately adjacent to our strainmeter. If large events, such as crack propagation from large frozen patches, or the opening of surface cracks on the glacier, are too far from our strainmeter to be measured directly, that is at a distance much greater than $10 \mathrm{~m}$, we may note the resultant effect of fracturing on the remainder of the glacier. Release of stress from large events will increase stresses on the surrounding bedrock with at least two consequences. The distribution of pressure and thickness in the basal water film will change, and in turn the flow of heat through rock and ice that is an essential part of the regelation process will be altered. The time constants of these two processes may differ widely. If one of the changes has a time constant of the order of ten seconds and the other one of some minutes, this could explain the form of the strain record, since both processes will affect traction at the ice/rock interface and hence elastic strains in the rock.

The increasing occurrence of strain events during summer and the larger amplitude of the events could fit the hypothesis of basal freezing due to changes of basal water pressure, although increasing surface fracturing due to faster flow offers another explanation. During winter months when the basal water flow is expected to be steady and of low discharge, and the glacier motion uniform, the heat-pump action may account for events.

Since one would expect some regularity of freezing action of any individual patch, either through time constants associated with flow and heat-pump action, or through increased changes of water pressure during daytime in summer months, the random time distribution of strain events does not appear to favour the freezing hypothesis. However if we are looking at events from a large number of freezing patches, each with a different time constant, the random timing of the sum of events is to be expected. To record a large number of events could involve a wide area of coverage. If this were the case, we should expect distant events to be recorded at all strainmeters. Since some $30 \%$ appear common to all strainmeters there is limited support for this hypothesis. As the surface is at least $80 \mathrm{~m}$ from our strain gauges, we should expect a high proportion of any events due to surface fracture to be common to all strain gauges. It appears however that we are dealing with more local phenomena for the majority of events, for which our hypothesis of fractured patches of ice frozen to bedrock can provide an explanation. While other explanations are also possible, the basic information on these events must be taken into account in any hypothesis of ice-bedrock sliding.

\section{Acknowledgements}

We are very grateful for the help of Professor R. A. Vivian in arranging access to the tunnels under the Glacier d'Argentière. G. Ballard, K. E. Evans, and J. Horsfall helped prepare and install the strainmeters. The equipment was purchased with grants from the Royal Society and the Science Research Council. During the field experiments D.J.G. was 
supported by the Science Research Council. Laboratory work was made possible by a grant from the Royal Society for the study of regelation effects (G. de Q.R.) and through provision of facilities in the Cavendish Laboratory by Professor D. Tabor, F.R.S., who is also thanked for helpful discussions.

\section{APPENDIX}

We consider an ice block, initially at its equilibrium melting temperature, when a pressure is suddenly applied. The immediate fall in temperature to the new equilibrium melting temperature is achieved by a small fraction of the ice block melting and extracting latent heat from the surrounding ice. A. B. Pippard (personal communication) has supplied a thermodynamic argument to show that the fraction of water in an ice/water block, $\alpha$, will increase if the block is subjected, adiabatically to a pressure change. If $S_{\mathrm{I}}$ is the entropy of the ice, and $S_{\mathrm{W}}$ the entropy of the water, the entropy of the block $S_{\mathrm{B}}$ is

$$
S_{\mathrm{B}}=\alpha S_{\mathrm{W}}+(\mathrm{I}-\alpha) S_{\mathrm{I}} .
$$

But $S_{\mathrm{W}}-S_{\mathrm{I}}=L / T$, where $L$ is the latent heat of ice, and $T$ the temperature. Then for an adiabatic change $\mathrm{d} S=\mathrm{o}$, and if $S(p, T)$,

$$
\mathrm{d} S_{\mathrm{I}}=\left(\frac{\delta S_{\mathrm{I}}}{\delta p}\right)_{T} \mathrm{~d} p+\left(\frac{\delta S_{\mathrm{I}}}{\delta T}\right)_{p} \mathrm{~d} T,
$$

and the system moves along the solidus

$$
\mathrm{o}=\left(\frac{\delta S_{\mathrm{I}}}{\delta p}\right)_{\text {melting }}+\alpha \frac{\mathrm{d}}{\mathrm{d} p}\left(\frac{L}{T}\right)+\frac{\mathrm{d} \alpha}{\mathrm{d} p} \frac{L}{T} .
$$

$\mathrm{d}(L / T) / \mathrm{d} p$ is very small compared to the other terms, $\left(\delta S_{1} / \delta p\right)_{\text {melting }}$ must be negative because

$$
\left(\frac{\delta S_{\mathrm{I}}}{\delta p}\right)_{\text {melting }}=-\left(\frac{\delta V}{\delta T}\right)_{p}-\left[\frac{c_{p}}{T}\left(-\frac{\mathrm{d} T}{\mathrm{~d} p}\right)_{\text {melting }}\right],
$$

and consequently $\mathrm{d} \alpha / \mathrm{d} p$ is positive, and water is produced on compression.

\section{REFERENCES}

Goldthwait, R. P. 1973. Jerky glacier motion and melt water. Union Géodésique et Géophysique Internationale. Association Internationale d'Hydrologie Scientifique. Commission de Neiges et Glaces. Symposium on the Hydrology of Glaciers, Cambridge, 7-13 September 1969, p. 183-88. (Publication No. 95 de l'Association Internationale d'Hydrologie Scientifique.)

Goodman, D. J. Unpublished. Creep and fracture of ice, and surface strain measurements on glaciers and sea ice. [Ph.D. thesis, University of Cambridge, 1977.]

Harrison, W. D. i972. Temperature of a temperate glacier. Fournal of Glaciology, Vol. i i, No. 61, p. $15-29$.

King, G. C. P., and Bilham, R. G. 1973. Strain measurements instrumentation and technique. Philosophical Transactions of the Royal Society of London, Ser. A, Vol. 274, No. 1239, p. 209-17.

McHugh, S., and Johnston, M. J. S. r977. An analysis of coseismic tilt changes from an array in central California. Fournal of Geophysical Research, Vol. 82, No. 36, p. 5692-98.

Neave, K. G., and Savage, J. C. 1970. Icequakes on the Athabasca Glacier. Journal of Geophysical Research, Vol. 75 , No. 8 , p. $135 \mathrm{I}-62$.

Robin, G. de Q. 1976 . Is the basal ice of a temperate glacier at the pressure melting point? Journal of Glaciology, Vol. 16, No. 74 , p. $183-96$.

Theakstone, W. H. 1967 . Basal sliding and movement near the margin of the glacier Østerdalsisen, Norway. Zournal of Glaciology, Vol. 6, No. 48, p. 805-16.

VanWormer, D., and Berg, E. 1973. Seismic evidence for glacier motion. Journal of Glaciology, Vol. 12, No. 65, p. $259-65$.

Vivian, R. A. 1975. Les glaciers des Alpes Occidentales. Grenoble, Imprimerie Allier.

Vivian, R. A., and Bocquet, G. I973. Subglacial cavitation phenomena under the Glacier d'Argentière, Mont Blanc, France. Fournal of Glaciology, Vol. 12, No. 66, p. 439-51.

Vivian, R. A., and Zumstein, J. 1973. Hydrologie sous-glaciaire au glacier d'Argentière (Mont-Blanc, France). Union Géodésique et Géophysique Internationale. Association Internationale d'Hydrologie Scientifique. Commission de Neiges et Glaces. Symposium on the Hydrology of Glaciers, Cambridge, 7-13 September 1969, p. 53-64. (Publication No. 95 de l'Association Internationale d'Hydrologie Scientifique.)

Weaver, C. S., and Malone, S. D. 1976. Mt St Helens seismic events: volcanic earthquakes or glacial noises? Geophysical Research Letters, Vol. 3, No. 3, p. 197-200. 


\section{DISCUSSION}

W. B. КАмв: In your experiments, if water were being expressed from the sample under the applied pressure, as needed in the heat-pump mechanism, one would expect the immediate temperature rise on release of pressure to be smaller the longer the time the pressure is applied, but your experiments do not appear to show that. Why?

G. DE Q. Robin: One purpose of the experiments was to test this idea. We could not apply the pressure pulse for less than $5 \mathrm{~s}$ with our system, and it appears that the major redistribution of water took place in that time. Subsequently some blocking action may have prevented escape of water, as seems likely from the relatively large recovery of temperature shown on the last (300 s) pulse in our series experiments, in comparison with the two other $300 \mathrm{~s}$ pulses shown. It would be interesting to design an experiment in which much shorter time pulses were used, provided we could match them with the response time of our temperature measurement. 